\title{
Development of Health Information System in TB Control Decision Support: Territoriality-Based Approach
}

\author{
Maryani Setyowati ${ }^{1}$, Noor Alis Setiyadi ${ }^{2}$, Suharyo $^{3}$, Dwi Feri Febiyanto ${ }^{4}$, \\ Slamet Sudaryanto 5 \\ \{maryani.setyowati@dsn.dinus.ac.id ${ }^{1}$,noor.setiyadi@ums.ac.id ${ }^{2}$, \\ suharyo@dsn.dinus.ac.id $\left.{ }^{3}\right\}$ \\ Universitas Dian Nuswantoro, Semarang, Indonesia ${ }^{1,3}$ \\ Universitas Muhammadiyah Surakarta, Surakarta, Indonesia ${ }^{2}$
}

\begin{abstract}
The Case Notification Rate of Tuberculosis (TB) in Sukoharjo regency in 2018 was the lowest. Various efforts have been undertaken, but the results have not yet reached the target. The research purpose was to develop a TB decision support system to assist in the TB suspects screening program in the Sukoharjo Regency. The method was a system development with System Development Life Cycle approach in Sukoharjo Regency. Research subjects were case subjects and system user subjects. The data was obtained by observation and interview. The results, the web-based and android systems tools were developed by management levels, from the village level, sub-district level, and the District Health Office Sukoharjo and tested at the district, community health center, and village levels. The TB Program's decision support system, it was easier for the parties concerned to see the distribution of TB sufferers in their working area and easy to determine further policies.
\end{abstract}

Keywords: Tuberculosis, Decision Support System, Suspect tracking, mapping

\section{Introduction}

Tuberculosis (TB) is still a global disease. Based on Sustainable Development Goals, 2030, its goal is to the reduction in tuberculosis deaths by $90 \%$ and decreasing incidence by $80 \%$ in 2030 compared to 2014. In 2015 there were an estimated 10, 4 million new cases of tuberculosis, or there are 142 cases per 100,000 population with as many as 480,000 cases of multidrug-resistant or MDR. Indonesia became the country with the second-largest number of cases in the world after India because $60 \%$ of new tuberculosis cases occurred in six countries in the world, namely India, Indonesia, China, Nigeria, Pakistan, and South Africa. Deaths from tuberculosis are estimated as many as 1.4 million deaths plus 0.4 deaths from tuberculosis with HIV. Although the number of deaths due to tuberculosis decreased by $22 \%$ between 2000 and 2015, tuberculosis remains the ten highest cause of death in the world in 2015, according to WHO's Global Tuberculosis Report in 2016. [1] 
It is remarkable that tuberculosis has posed a threat to public-health since $1800 \mathrm{~s}$. in the race to combat a disease that knows no boundaries, it is necessary to have a conceptual and clear understanding tuberculosis overall.[2]

In Indonesia, the prevalence of tuberculosis by 660 per 100,000 population means that as many as $0.65 \%$ of the population in Indonesia is affected by tuberculosis or equal to 1.6 million cases recorded 1 million new cases each year.[3] Persahabatan Hospital, a referral hospital located in Jakarta received every month received as many as $1000 \mathrm{~TB}$ cases suspected TB cases per month, while for his cases found as many as $3000 \mathrm{~TB}$ cases per month and 1500 of them were positive TB.[4]

The study from Indonesia, Ratna Rahayu, and colleagues showed that The multivariate analysis showed the dominant factors that influence the occurrence of TB suspect, "education", "income", "ashamed of having TB", "TB treatment is very costly", and "share dish", distribution of health education booklet to teachers and parents.[5]

As a regency located in Central Java Indonesia, Sukoharjo stated that Case Notification Rate (CNR) achievement in Sukoharjo Regency in 2017 was the 3rd lowest after Semarang Regency and Magelang Regency, with 28.7 per 100,000 population. However, the CNR of all TB cases was ranked second lowest after Magelang District with a figure of 52.5 per 100,000 population. Sukoharjo had a population of 893,884 residents in 2017 with an estimated TB finding of 2,708 cases, but only 117 cases were reported, which consisted of 114 new cases and three repeat treatments.

Also, Sukoharjo reported 16 deaths in TB in 2016, and a Case Fatality Rate (CFR) of 0.04. In his research, it was found that new TB cases and recurrence in each puskesmas area were explained in 3 categories, namely from 12 regions there were $58 \%$ of puskesmas, or seven community health center experienced a decrease in new cases and recurrence. Whereas $42 \%$ or five community health center fluctuate or go up and up.[6]

The principles and strategies of the TB Program in 2015-2020 include strengthening TB program leadership in districts/ cities and supporting systems, increasing access to quality TB services. An increase in quality and impartial TOSSTB (Find Treat to Heal) services to patients, control of risk factors for TB transmission, increase TB partnerships through the TB Gerdunas forum, increase community independence in TB control, and strengthen program management. One of the supporters to achieve success in eradicating TB is the application of an appropriate information system. Strengthening the health system is one of the six strategies to stop TB, which states that information weaknesses include monitoring and evaluation, including poor quality vital statistics and geographic information systems for disease surveillance. For this reason, it must be done, namely ensuring a recording and reporting system that can work in synergy with the national health information system that can be used as a model for analyzing problems and being able to improve performance in the regions.[7]

The information system for recording and reporting TB cases in the work area of the District Health Office (DKK) Sukoharjo, has not been fully integrated between sections. However, it already has its server but has not been optimized, so the data reporting process is still limited to online delivery and not real-time. It was integrated directly. So that the form of information about TB is only limited to medical data of 
patients, the total number of patients in the scope of community health center presented in tables and diagrams cannot present TB cases by region through mapping.

On the other hand, Sukoharjo government five efforts related to TB namely, strengthening of legislative support, the private sector, spiritual figure, community leader and other stakeholders, strengthening health education and behavior practices, strengthening the physical environment in the company, public facilities, housing, strengthening of village health volunteer to find the suspected TB, and strengthening health workers, health facilities and easy access to services.

A preliminary study stated that there were still gaps or differences between estimates of TB case and TB cases found, including estimates of suspected resistant TB. For this reason, an innovative decision support system is needed to assist the Sukoharjo District Health Office in restricting the gaps. So, the achievement of TB suspects selection is more effective and efficient.

The study from Korea, Woo J-I, and colleagues showed that a decision support system for chronic disease administration, a recommendation message was obtained through a website service that supports self-management and screening schedule.[8]

An information system of TB developed by the ministry of health, Indonesia, SITT (Integrated Tuberculosis Information System) is a form of a web-based application that can be accessed online. The development of SITT is carried out to support TB surveillance activities and, in the process, is carried out in collaboration with the Center for Data and Information (Pusdatin) Ministry of Health of the Republic of Indonesia. SITT development aims to facilitate the implementation of further analysis between cases with logistics, cases with laboratories, logistics system alerts, inventory studies, and capture to capture. [9]

The District Health Office has been implemented SITT as mandatory from the ministry. The problems are items in SITT that are not following TB services currently related to sputum examination and display of SITT applications that are still in tables. There is no map display for TB cases desired by TB officer. SITT was designed for recording and reporting systems only so that it does not produce the other information to support another TB program.

This research aims to develop a regional-based TB program decision support system in Sukoharjo Regency, using the SDLC (System Development Life Cycle) approach or system development life cycle.

This system was to support TB program policies such as prioriticing an area in TB suspects selection.

\section{Methods}

This study was an information system development with SDLC (System Development Life Cycle) approach, which is a system development cycle whose activities are interrelated and sustainable. [10]

The study area was the working area of the Sukoharjo District Health department. The TB cases recorded in the district between 2018 to April 2019 were inputted in the system to graph in mapping. Many research assistants were trained to collect the data. 
The interview was obtained Head of district health office, chairperson of disease control and prevention, chairperson of infectious disease control, the TB data officer, the Head of data and information, the Head of the Community health center and the Community health center TB programmer.

The theme interviewed were TB program data management in community health center and district health office as well as observing the form of information systems that are running. The inclusion criteria were considered by informed consent. In collecting data, the instruments used are observation and interview guidelines and questionnaires.

Quantitative data processing using the SPSS program and applications for qualitative data processing with the Nvivo application. The processed data will then be analyzed, namely quantitative analysis for quantitative data with a descriptive analysis of TB respondent data recorded in 2018 and until February 2019. Then describe the database correlation table, Data Flow Diagrams (DFD), and describe the support system flow decisions.

The qualitative data that has been processed is carried out qualitative analysis by narrating the results of interviews from informants.

For the SDLC method in designing a decision support system consists of the following stages:

- Conduct a system user needs study (feasibility study)

- Analyzing TB program decision support systems in the Sukoharjo district

- Perform the system design stage based on the TB Program system analysis

- Testing the system offline (off-network/ offline)

- Online system testing

- Perform system evaluations by system users

- Perform system improvements based on user input

\section{$3 \quad$ Results and Discussions}

Sukoharjo Regency is geographically located at 7032'17" - 7049'32" southern latitude and 110042'06,79' - 110057'33,7' east longitude. The border of Sukoharjo Regency in the north is bounded by Surakarta City, in the south with Wonogiri Regency, in the west with Boyolali Regency, and in the east with Karanganyar Regency. This research was conducted in the working area of the Sukoharjo District Health Office, which has 12 puskesmas. Still, for the system trial, one selected puskesmas was selected according to the criteria. 


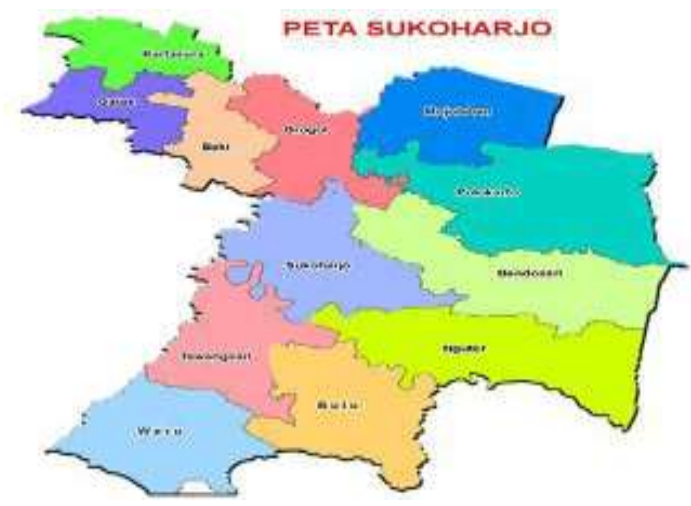

Fig. 1. Sukoharjo map

TB data has been managed by the district level data officers from puskesmas staff reports via SITT online, but its process is still not going well.

TB officer in community health center level sent the TB recording by excel files, and email it to the district. These data are only recording and reporting information. Still, they can not explain or assist in making policies related to which regional priorities are emphasized in the screening of suspects by knocking door and mass sputum activity test (ketuk pintu and grebek dahak).

Currently, the existing information systems used can not provide enough to support the decision, such as prioritizing an area in TB suspects collection.

Of this research, the district health office of Sukoharjo requested that the system not increase the workload of TB officers, but rather make it easier to help make TB program decisions, especially in TB suspects screening. Besides, the health department hopes that the system does not need to re-input and color the map display. The map that was displayed to be made more informative by displaying the classification of risk is low, medium, and high. follows:

Results of TB case data collection on cases recorded in 2018 and 2019 by sex as

Table 1. Distribution of TB Patients by Sex

\begin{tabular}{lll}
\hline Sex & Frequency & Percent $(\%)$ \\
\hline Female & 155 & 56.99 \\
Male & 117 & 43.01 \\
\hline
\end{tabular}

Based on the distribution table of TB patients by sex recorded in 2018 and early 2019 , female TB patients by $56.99 \%$ higher than male TB patients by $43.01 \%$.

Whereas the types of TB obtained from TB cases recorded in 2018 and early 2019 are as follows: 
Table 2. Distribution of TB Patients by Type of TB

\begin{tabular}{rcr}
\hline Type & Frequency & Percent $(\%)$ \\
\hline Lung TB & 261 & 94.91 \\
Extra Pulmo & 14 & 5.09 \\
\hline
\end{tabular}

Type of TB showed that the majority were pulmonary TB $(94,91)$.

When compared to the number of TB patients by sex and type of TB can be seen in the figure below:

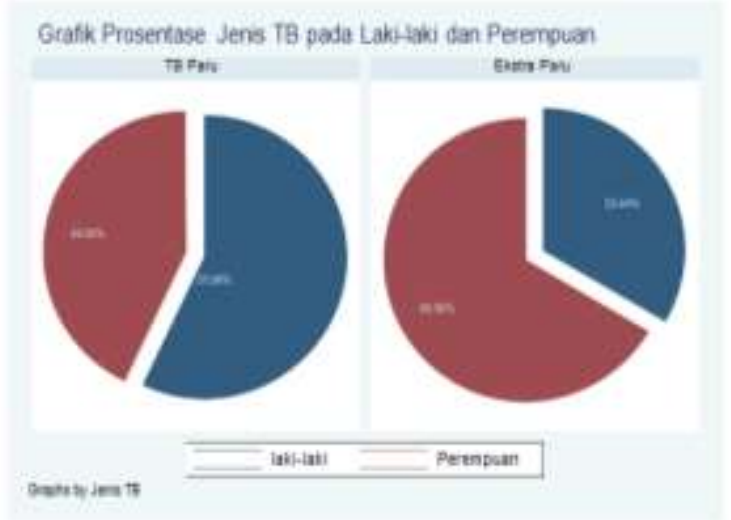

Fig. 2. Graphic Comparison of the number of TB patients by sex and type of TB.

Figure 2 showed that the majority of lung TB were male (57.08), besides patents who had extra lung, female higher than male $(66.56 \%)$.

The next step is to design a TB Program decision support system with the following steps:

1. Making a new system user diagram or Usecase diagram.

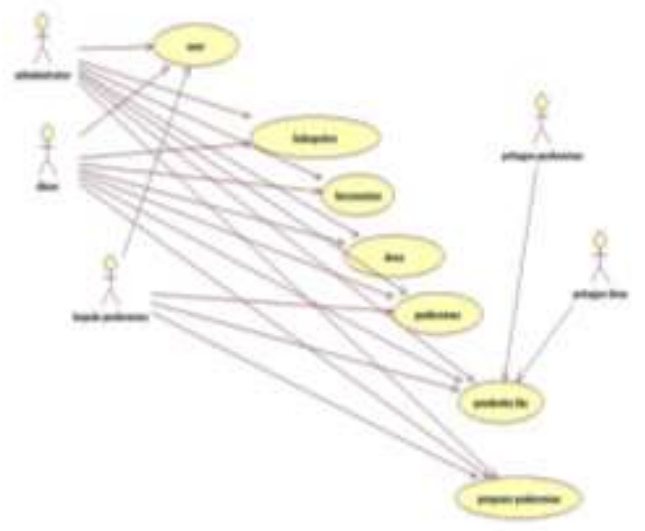

Fig. 3. Usecase Diagram 
Usecase diagram made to detect actors in the system, which consists of the user such as :

a. Administrators who have full access rights where the administrator can access all forms in the system.

b. Public Health Officer or District Health Office have access to all forms except district data collection, with the main task of monitoring performance in each puskesmas and programs proposed by puskesmas.

c. The head of the primary health care has access to register the users for the puskesmas staff and has a program to manage the area.

d. TB programmer was an officer on the Community health care level who have access to data on TB patients in the villages and provide input to the puskesmas head to carry out TB programs in their area.

2. Creating an Activity Diagram to illustrate activity on the system.

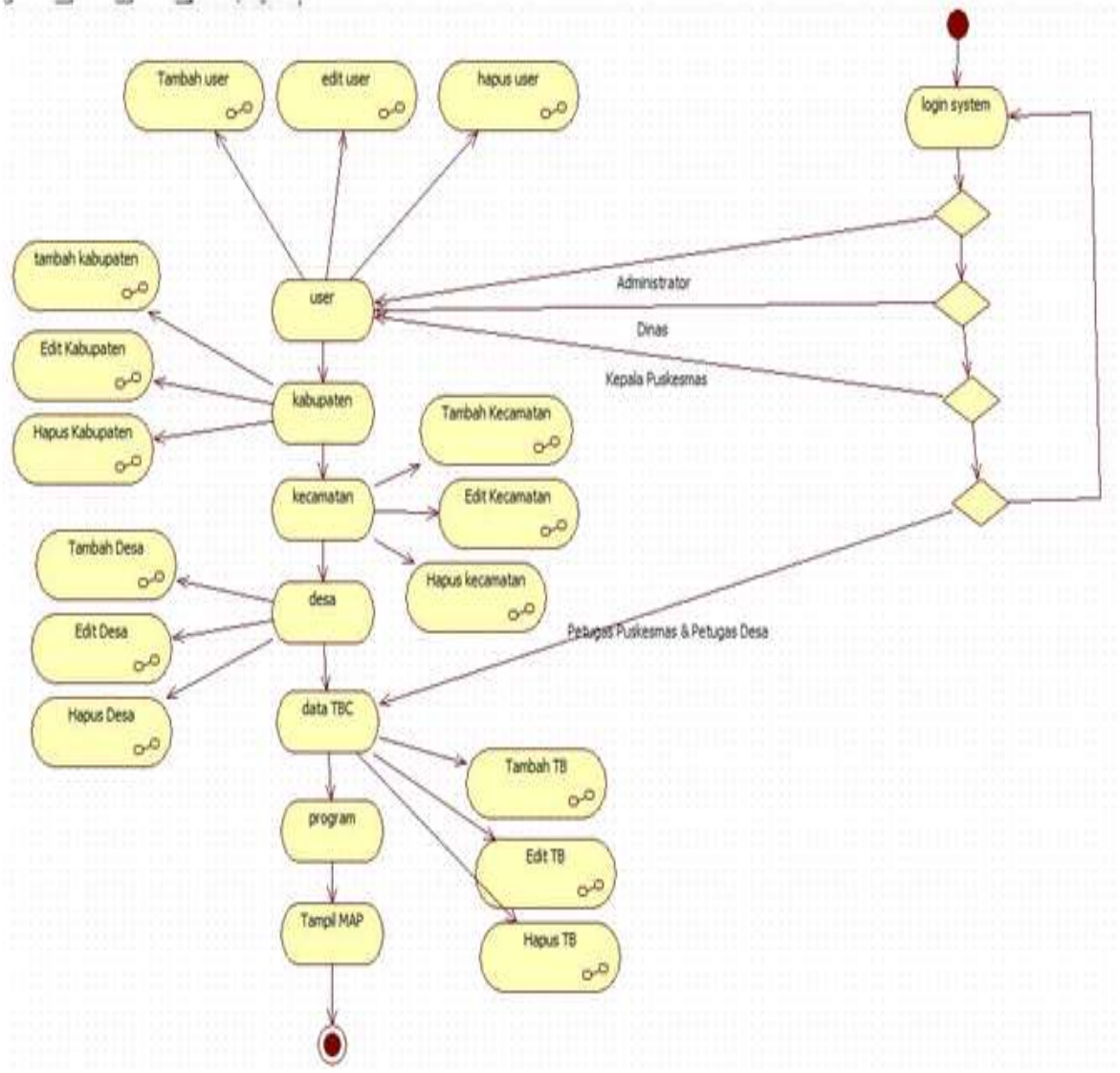

Fig. 4. Activity diagram

The activity diagram of the system created illustrates the system login activities as an administrator, department, head of puskesmas, and puskesmas officers. And the right of access to the table can be added and edited data. 
3. Creating Squencial Diagram

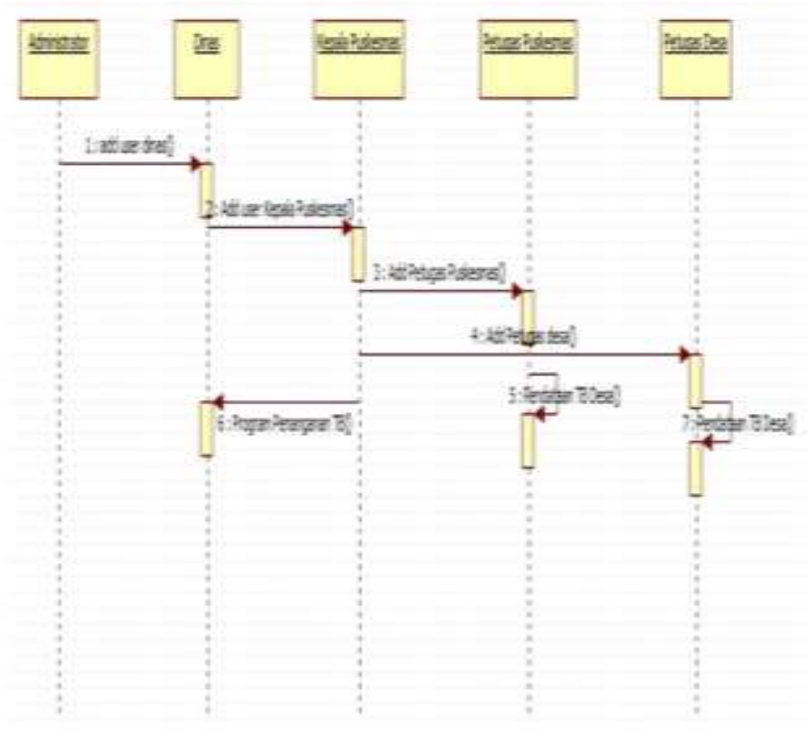

Fig. 5. Squencial Diagram

Sequential diagram of the system that has been made is the following :

- The initial administrator will create a user for service

- After that, the Health service officer will create a user for each head of community health center

- The head of the puskesmas creates users for officers and villages and makes programs based on input from community health center and village officials

- Community health center officer and village staff will collect TB data

4. Making the Normalization of data for the system developed. Normalization of this data consists of 2 stages:

- The use case diagram developed from stage 1NF. Then the tables used are consisting of id_desa and villages, id_kec and sub-districts, id_kab, and districts.

- $2 \mathrm{NF}$ normalization as the second normalization form in the village, sub-district and district user field tables had been separated into individual tables where relations in the user table use the id_desa field to relate to the village table, id_kec to relate to the subdistrict table, and id_kab to relate to the district table. 
5. Making an Entity Relationship Diagram (ERD) was to form relations between tables. It can be seen in Figure 6 below.

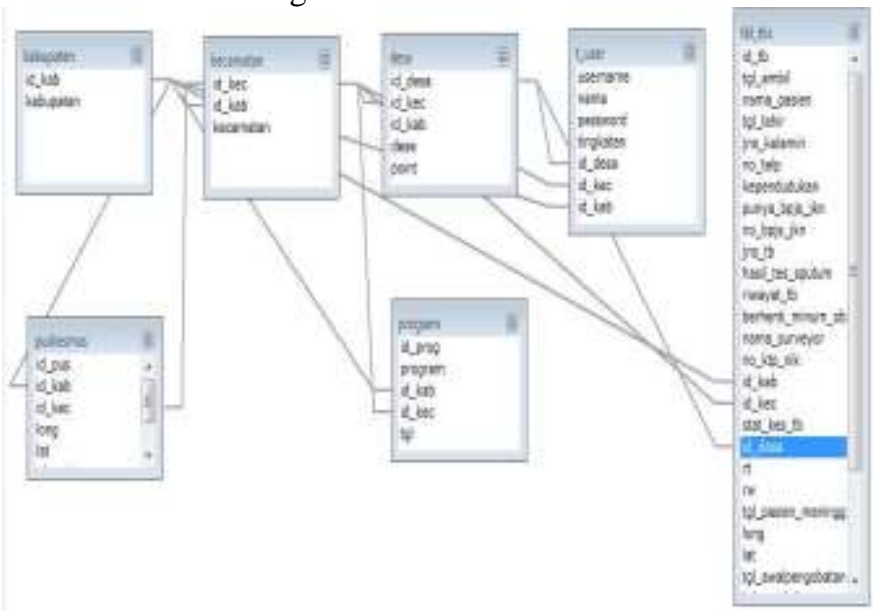

Fig. 6. ERD of a new system

\section{Program Design and Implementation}

This activity is the stage for designing menus in the TB Program decision support system. The program used to design using web-based programs and database programs using MySQL. The design below:

A. Username and password user on login form used for users to enter the system, show by figure 7:

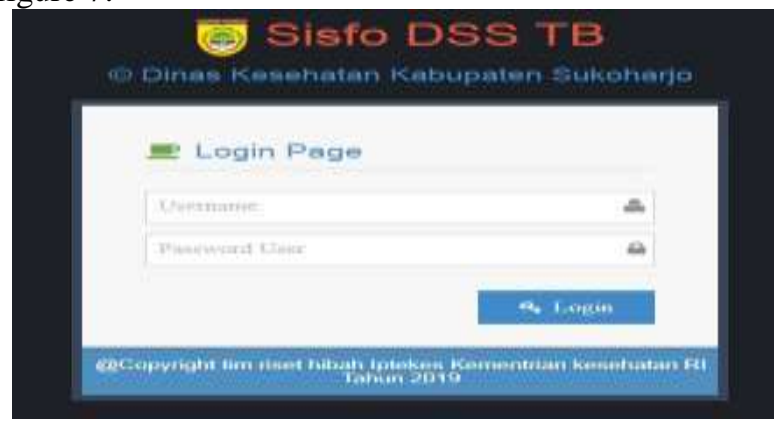

Fig. 7. Login menu of Implementation program

On this login form, the user had to fulfill the right username and password as first registration, if in the database match with the username and password so that it will be directed to inside TB web appropriate with the user level. If there wrong user and password entered on the login form, there would be an error message. 
B. Main page display belonging on SPK-TB

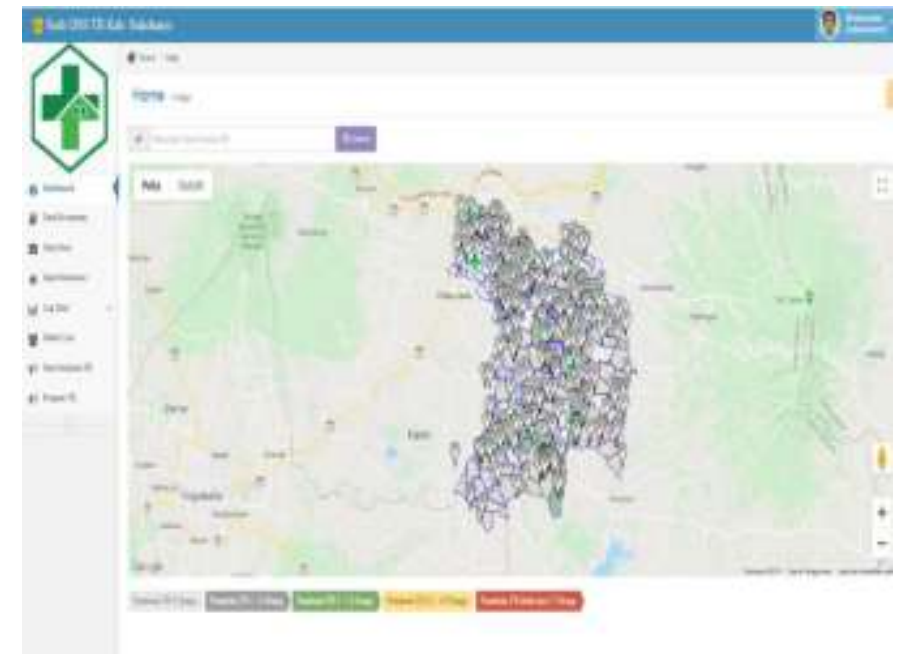

Fig. 8. SPK TB main page of the Implementation program

The main page, when the user log-in, it will show maps of Sukoharjo Regency and points of TB patient corresponding with recorded data, also color shows the number of TB patients. White color show amount of $1-4$ patients, green color $5-11$ patients, yellow color $12-16$ patients, and red shows $\geq 17$ patients in the village.

C. The display of TB patient fulfillment form equipped with a TB patient input menu and headed village. TB patient data not only can be inputted with computers but also with handphones or smartphones because of this system, SPK-TB, program created as an android based application.

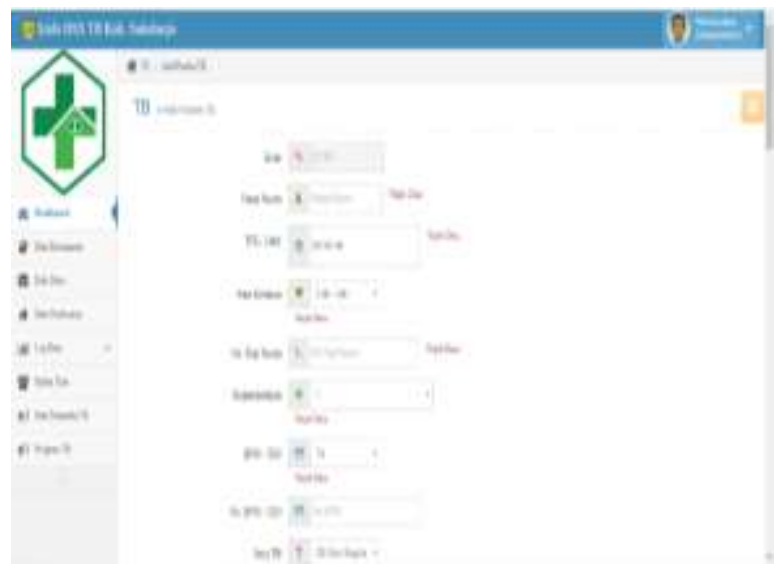




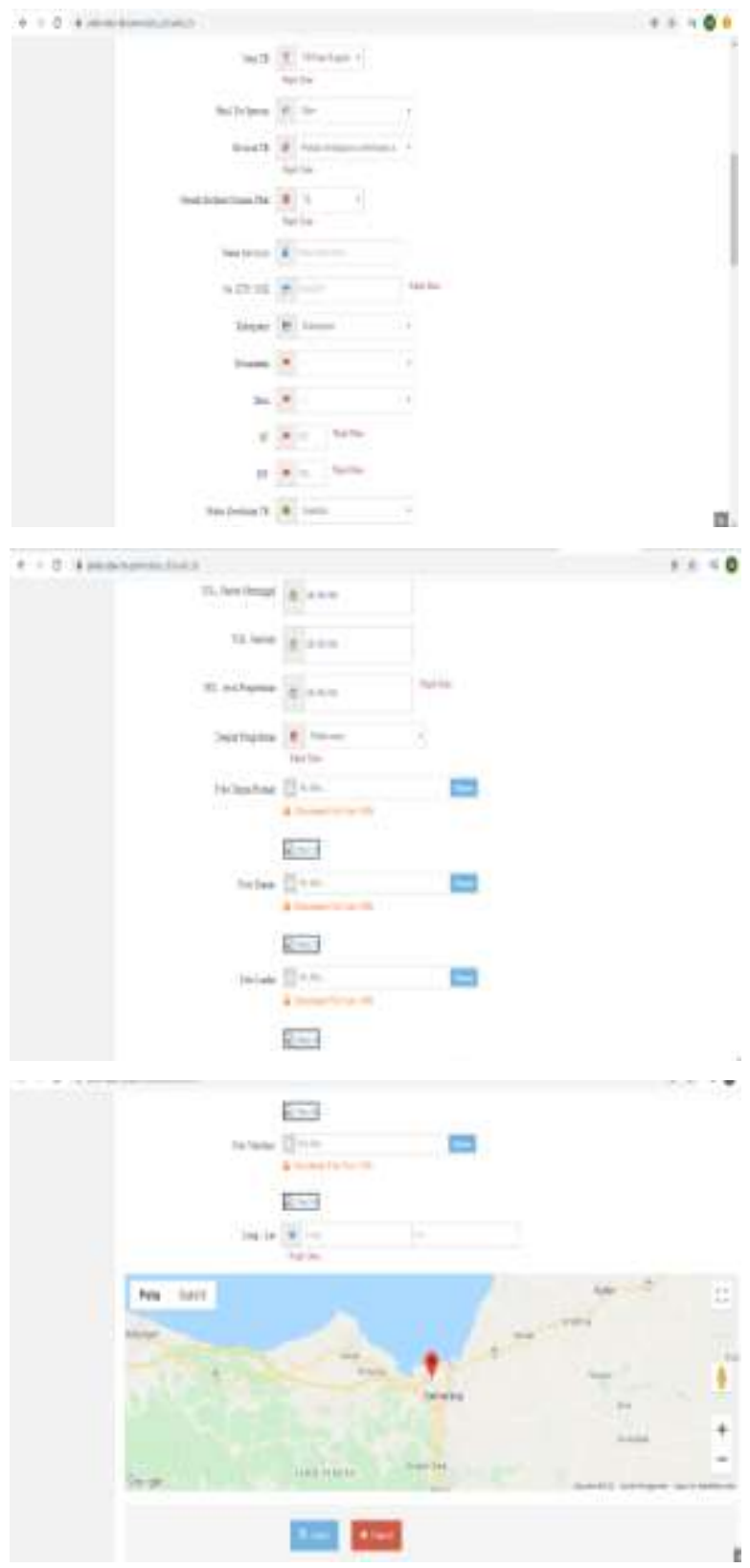

Fig. 9. TB Patient Form for Implementation Program

This TB input form used by community health center officer or village coordinator that visits TB patient home. Both input appropriate patient data in this form, and this from equipped with maps where patients live. 
D. The display of the TB program menu conducted by the community health center officer.

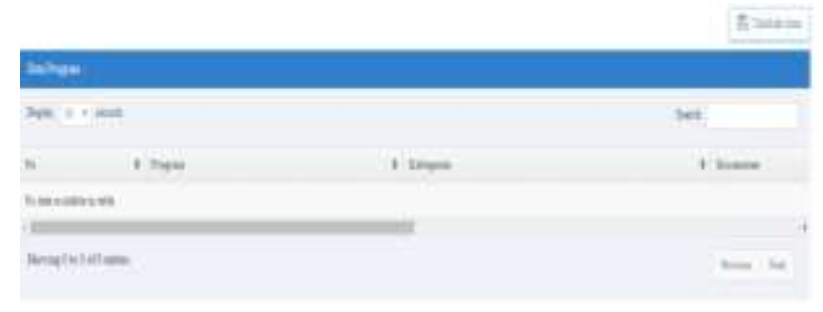

Fig. 10. TB Program Implementation

The TB Program menu was used by the puskesmas to include activities that were following the TB case findings in each puskesmas. If TB cases are found to be greater than 17, the Head of the Community Health Center is required to provide a program that aims to deal with the area affected by TB where the TB Program will be followed up by the Sukoharjo District Health Service as input for future steps. By entering the activity into the TB Program Form menu shown in the following figure:

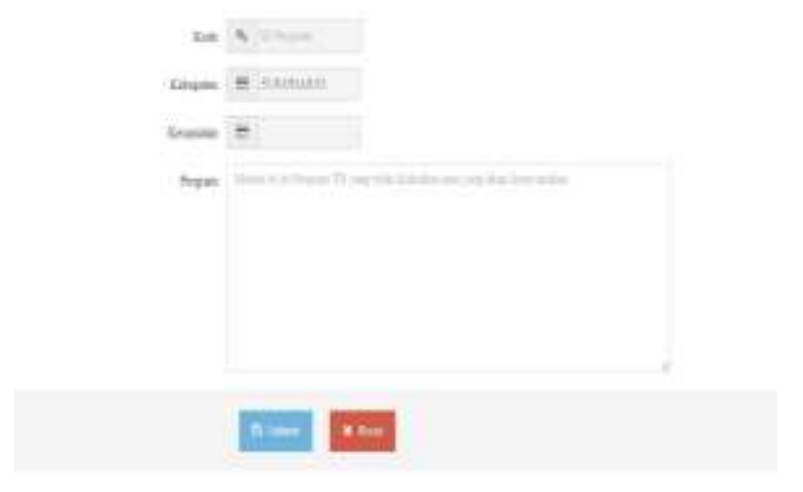

Fig. 11. Menu Form of TB Program Implementation

7. Implementation of the TB Decision Support System trial; at this stage, there are two activities:

- Internal testing is carried out by testing the system that was made, namely SPK-TB web-based, by the research team offline or offline by activating the interface created and seeing the smooth system that has been created using computers and mobile phones. After the offline trial has been successful, the next trial was an online trial using data communication or online to see the location of TB patients based on villages in Sukoharjo Regency. 
- An external trial for SPK-TB is carried out using a computer device and mobile phone or smartphone. In using this system on a computer device by accessing the web that had been made, namely https://sisfo-dsstb.com/. To be able to run SPK on mobile or smartphone is required by logging in or logging on to the web https://sisfo-dss-tb.com/ which will then appear in the bottom selection of images to download the application for the mobile device.

8. Evaluation of the system trial in the field with the system user, this activity is carried out in 2 stages:

- Phase 1 of the system trial at the Sukoharjo Health Service Officer was obtained there directly accessing the web-based SPK-TB and looking at the menus and data contained in the system using a laptop or mobile device. Based on this trial, it was found that there was data on the date of death that was filled in automatically; the location of the pointer was not right in the destination village. There were additional data for the TB program that needed to be filled in by the Head of the Community Health Center.

- Phase 2 of the trial at the selected Community Health Center was Bulu Community Health Center in Sukoharjo District, which is the puskesmas located farthest from the Sukoharjo DKK and had recorded and reported with SITT. This trial involves the village coordinator or village midwife and directly practices how to input TB patient data using the SPK-TB application using a mobile phone or smartphone owned by each village midwife. Based on the results of the Phase 2 trial, it was found that the TB Community Health Center programmer and the village midwives were able to input data using mobile and laptop devices.

Research carried out in several stages to achieve research objectives, there are :

a) The users were developed at two levels of decision making of the TB program at the level of the work area of the health department, namely the level of district or city health service and puskesmas. Theye refer to a statement from the Head of the Disease Prevention section (P2) at the District Health Office level, which requires a system that facilitates decisions for the TB Program, including crosssectoral involvement. Based on the research of the health service system in Uttar Pradesh, India, which explains that the provision of traceable information at all levels of management is the key to strengthening the health system and can improve the quality of health services.[11] Analysis of needs based on research on Information Systems Requirements Analysis in Yogyakarta cites from B.Yanmarshus stated that the needs analysis is the main key to get information about the software needed by the user [12]

b) Analyzing the TB Program decision support system in the Sukoharjo district, it was found that the policymakers were at the district and puskesmas level. Related to the territorial-based suspecting netting policy, so far, TB data management at the Sukoharjo PHO level is managed by data officers who are supported by TB programmers in puskesmas using SITT. Also, there is the use of P-care in health centers. However, the existing system has not been able to display in the form of 
mapping, so we need a system that can support decisions for the management level in the screening of TB suspects. It is consistent with a limited set of processes related to the use of data for decision making at the district level. [13]

c) The levels of users were developed, including the village level. Village coordinator or village midwife who contacts directly to TB sufferers' locations, making it easier for Community Health Center to monitor TB distribution based on reports from village coordinators or village midwives. Whereas at the DKK Sukoharjo level, they received reports from the puskesmas by looking at the spread of TB patients in their working area and were able to monitor the performance of the Community Health Center based on TB program records. The existing information system is not yet effective because there are still many programs that have not been implemented well. After all, many Community Health Center are late or not the same once report the data to the Rokan Hilir District Health Office so that problems in the health sector have not been resolved. [14]

d) The system designed was to emerge the objects to support the decision. The object and how it relates to one another with the relationship between aggregation and generalization.[15] in the usecase diagram that has been made can be seen by the actors of the new system consisting of actors based on management level, namely administrator, department, head of Community Health Center, and Community Health Center and village officials, which have their respective roles under their duties.

e) Trial the system was undertaken to get whether the program designed can be run well or not.

f) Other issues were the limitations encountered in the system Village area-based TB program decision support and trial run smoothly.

g) The Sukoharjo DKK can use the implementation of online system trials conducted in the field directly to find out whether the system created by using internet access. It was following research on the development of health information systems found that the last stage in the development of information systems is by testing the system that results in testing validation that all functional and nonfunctional needs have been met by the system designed. Incompatibility testing, the system results have obtained the information built can run well in almost all browsers. [16]

\section{Conclusions}

Based on the study of the needs of system users in the Sukoharjo DKK and Bulu district of Sukoharjo District, it was found that at the management level, the puskesmas needed an accurate TB patient report from the village coordinator. Whereas at the management level of Sukoharjo requires a decision support system that can see the distribution of TB cases accurately and precisely. TB Program Decision Support System so far has not been in the form of web and android because the Sukoharjo got TB Program reports based on reports from puskesmas in its working area using SITT, while SITT is only in the form of recording and reporting in the form of numbers and not in the form of mapping that can facilitate the 
management level sees the distribution of TB cases in their working area. A health information system was developed and tested on several levels: district, Community Health Center as sub-district, a village as data input officer. The Community Health Center level could get information in mapping and offer the TB program based on its decision.

Acknowledgments. This research ran smoothly with the support of various parties. For that, we say many thanks to Badan Penelitian dan Pengembangan Kesehatan (Litbangkes) Kemenkes Republik Indonesia (Health Research and Development Agency, Ministry of Health Indonesia) has given the 2019 IPTEKKES research grant to the research team; Dean of the Faculty of Health,Science Dian Nuswantoro University, and their staff; Dean of the Faculty of Health Sciences Muhammadiyah Surakarta and his staff; Head of the Health Office of Sukoharjo Regency, Central Java and their staff; Head of Primary Health Care Bulu, Sukoharjo Regency and their staff; Colleagues and parties who have helped to carry out the 2019 IPTEKKES research to completion smoothly.

\section{References}

[1]. Dinas Kesehatan Provinsi Jawa Tengah. Profil Kesehatan Provinsi Jawa Tengah tahun 2018 [Internet]. Semarang; 2018. Available from: http://dinkesjatengprov.go.id/v2018/dokumen/profil_2018/files/downloads/Profil Jateng 2018 cetak.pdf

[2]. Fogel N. Tuberculosis: A disease without boundaries. Tuberculosis [Internet]. 2015;95(5):527-31. Available from: http://dx.doi.org/10.1016/j.tube.2015.05.017

[3]. Rina Anggraeni. Kelompok Usia Produktif Rentan Terkena Tuberkulosis. Sindo News [Internet]. 2017 Nov; Available from: https://lifestyle.sindonews.com/read/1261459/155/kelompok-usia-produktif-rentanterkena-tuberkulosis-1511898948

[4]. Ramadhani B. Usia Produktif Rentan TBC Kebal Obat _ Republika Online. Republika News [Internet]. 2012; Available from: https://www.republika.co.id/berita/nasional/umum/12/11/23/mdxymt-usia-produktifrentan-tbc-kebal-obat

[5]. Rahayu SR, Katsuyama H, Katsuyama M, Ota Y, Djaja Semadi NP. Tuberculosis Suspect in the Companies in Semarang District Indonesia; Case-Control Study. J Kesehat Masy. 2017;12(2):167-76.

[6]. Setiyadi NA, Bagaskoro A, Dyah R, Magdalena A. The 8 th University Research Colloquium 2018 Universitas Muhammadiyah Purwokerto GAMBARAN KASUS TUBERKULOSIS TAHUN 2013-2016 DI JAWA TENGAH : STUDI DESKRIPTIF DI KABUPATEN SUKOHARJO TUBERCULOSIS CASES GRAPHING IN 2013-2016 IN SUKOHARJO REGENCY: A DESCRIP. 2018;2016. Available from: http://repository.urecol.org/index.php/proceeding/article/view/354/345

[7]. Kementrian Kesehatan RI. Prinsip dan strategi Program TB tahun 2015 -2020. 2015; Available from: https://www.tbindonesia.or.id/page/view/7/prinsip-dan-strategi-program 
[8]. J.-I. W, J.-G. Y, Y.-H. L, U.-G. K. Healthcare decision support system for administration of Chronic diseases. Healthc Inform Res [Internet]. 2014;20(3):173-82. Available from: https://europepmc.org/articles/PMC4141131;jsessionid=E23A922F0692B766938EDF5E EA1D157B

[9]. RAMADHANI NR. EVALUASI SISTEM INFORMASI TUBERKULOSIS TERPADU (SITT) DI RUMAH SAKIT PARU RESPIRA YOGYAKARTA DAN DINAS KESEHATAN PROVINSI DAERAH ISTIMEWA YOGYAKARTA DENGAN METODE TECHNOLOGY ACCEPTANCE MODEL (TAM) [Internet]. Universsitas Muhammadiyah $\quad$ Surakarta; $2018 . \quad$ Available from: http://eprints.ums.ac.id/68506/12/Naskah Publikasi-18.pdf

[10]. Ralph M. Stair GR. Principles of information systems [Internet]. 10th ed. USA: 10th ed. USA: Course Technology, Cengage Learning; 2012. Available from: http://site.iugaza.edu.ps/kdahleez/files/2014/09/stair78292_0538478292_02.01_chapter01 .pdf

[11]. Kapadia-Kundu N, Sullivan TM, Safi B, Trivedi G, Velu S. Understanding health information needs and gaps in the health care system in uttar pradesh, India. J Health Commun [Internet]. 2012;17(SUPPL. 2):30-45. Available from: https://www.tandfonline.com/doi/pdf/10.1080/10810730.2012.666625?needAccess=true

[12]. Alimuddin Yasin, MZ Yumarlin TF. Analisis Kebutuhan Sistem Informasi di LPK RJCOMP Yogyakarta. Semin Nas Inform [Internet]. 2017;1(1):111-6. Available from: http://e-journal.potensi-utama.ac.id/ojs/index.php/SNIf/article/view/251

[13]. Raeisi AR, Saghaeiannejad S, Karimi S, Ehteshami A, Kasaei M. District health information system assessment: A case study in Iran. Acta Inform Medica [Internet]. 2013;21(1):30-5. Available from: https://www.ncbi.nlm.nih.gov/pmc/articles/PMC3612431/pdf/AIM-21-1-8.pdf

[14]. Isnaini. Efektifitas Pelaksanaan Sistem Informasi Kesehatan Online Pada Dinas Kesehatan Kabupaten Rokan Hilir. Jom Fisip [Internet]. 2017;4(2):1-14. Available from: https://jom.unri.ac.id/index.php/JOMFSIP/article/view/15121/14668

[15]. Dewi LP. Perancangan Sistem Informasi Dengan Metode Use Case Driven Object Modelling (Studi Kasus: Verifikasi Data Pada Penerimaan Siswa Baru). 2011; Available from: http://repository.petra.ac.id/15654/1/Use_Case_-Full_Paper.pdf

[16]. Herlambang TW, Aknuranda I, Saputra MC. Pengembangan Sistem Informasi Kesehatan Berbasis Web Berdasarkan Model Organisasi Dan Manajemen Kesehatan Primer “ ANDAL ." J Pengemb Teknol Inf dan Ilmu Komput Univ Brawijaya [Internet]. 2018;2(4):1602-10. Available from: http://j-ptiik.ub.ac.id/index.php/jptiik/article/view/1282/462 